\title{
A long-acting glucagon-like peptide-1 analogue attenuates induction of plasminogen activator inhibitor type- 1 and vascular adhesion molecules
}

\author{
Hongbin Liu ${ }^{1,2}$, Anthony E Dear ${ }^{1,2}$, Lotte B Knudsen ${ }^{3}$ and Richard W Simpson ${ }^{1,2,4}$ \\ ${ }^{1}$ Australian Centre for Blood Diseases, Monash University, 6th Floor Burnett Tower, 89 Commercial Road, Prahran 3181, Melbourne, Victoria, Australia \\ ${ }^{2}$ Eastern Clinical Research Unit, Biotechnology Division, Monash University, 6th Floor Burnett Tower, 89 Commercial Road, Prahran 3181, Melbourne, Victoria, \\ Australia \\ ${ }^{3}$ Novo Nordisk A/S, Novo Nordisk Park, DK-2760 Måløv, Denmark \\ ${ }^{4}$ Department of Diabetes and Endocrinology, 4th Floor Clive Ward Centre, Box Hill Hospital, Arnold Street, Box Hill 3128, Melbourne, Victoria, Australia \\ (Correspondence should be addressed to A E Dear; Email: anthony.dear@med.monash.edu.au)
}

\begin{abstract}
Glucagon-like peptide-1 (GLP-1) administration attenuates endothelial cell dysfunction in diabetic patients and inhibits tumour necrosis factor $\alpha$ (TNF)-mediated plasminogen activator inhibitor type-1 (PAI-1) induction in human vascular endothelial cells. The short half-life of GLP-1 mediated via degradation by the enzyme dipeptidyl peptidase 4 mandates the clinical use of long-acting GLP-1 analogues. The effects of a long-acting GLP-1 analogue on PAI-1 and vascular adhesion molecule expression in vascular endothelial cells are unknown. In this report, we demonstrate for the first time that the treatment with liraglutide, a long-acting GLP-1 analogue, inhibited TNF or hyperglycaemia-mediated induction of PAI-1, intercellular adhesion molecule-1 and
\end{abstract}

vascular cell adhesion molecule-1 mRNA and protein expression in a human vascular endothelial cell line. In addition, treatment attenuated TNF- or hyperglycaemiamediated induction of the orphan nuclear receptor Nur77 mRNA expression. Taken together, these observations indicate that liraglutide inhibits TNF- or glucose-mediated induction of PAI-1 and vascular adhesion molecule expression, and this effect may involve the modulation of NUR77. These effects suggest that liraglutide may potentially improve the endothelial cell dysfunction associated with premature atherosclerosis identified in type 2 diabetic patients.

Journal of Endocrinology (2009) 201, 59-66

\section{Introduction}

Type 2 diabetes is characterized by accelerated atherosclerosis (Hobb 2006). Elevated tumour necrosis factor $\alpha$ (TNF) levels and hyperglycaemia are implicated in diabetesassociated endothelial cell dysfunction and may be causal in premature atherosclerosis (Morigi et al. 1998, Liu et al. 2005, 2008, Norata et al. 2006, Kumar et al. 2007, Iwasaki et al. 2008).

TNF and hyperglycaemia have been shown to induce plasminogen activator inhibitor-1 (PAI-1) and vascular cell adhesion molecule (ICAM-1 and VCAM-1) expression in human vascular endothelial cells (Morigi et al. 1998, Liu et al. 2005, 2008, Norata et al. 2006, Kumar et al. 2007, Iwasaki et al. 2008). PAI-1 and vascular adhesion molecules, including VCAM-1 and ICAM-1, are elevated in diabetes and are thought to participate in the pathogenesis of atherosclerosis (Sobel et al. 1998, Blankenberg et al. 2003). Interestingly, mice with a targeted deletion of the PAI-1 gene are protected from the development of biochemical abnormalities associated with endothelial cell dysfunction and development of atherosclerosis (Eitzman et al. 2000, Mao et al. 2004).

Liraglutide, an acylated glucagon-like peptide-1 (GLP-1) analogue, has a half-life of 10-14 h allowing once-daily s.c. injection (Elbrønd et al. 2002). Clinical trials of liraglutide in patients with type 2 diabetes demonstrate improved levels of both fasting and postprandial glucose, improvement in $\beta$-cell function, ability to delay gastric emptying and a reduction in plasma glucagon concentration and weight loss (Elbrønd et al. 2002, Juhl et al. 2002, Degn et al. 2004, Vilsboll et al. 2007).

In vivo studies demonstrate that native GLP-1 regulates vascular tone and endothelial function (Golpon et al. 2001, Yu et al. 2003), and a clinical study has reported reduced endothelial dysfunction in type 2 diabetic patients with established coronary artery disease (Nyström et al. 2004). In vitro native GLP-1 attenuates TNF $\alpha$-induced PAI-1 expression in human vascular endothelial cells, an effect that may utilize the orphan nuclear receptor NUR77 (Liu et al. 2008) and provide further evidence for GLP-1-mediated reduction in endothelial cell dysfunction. 
A

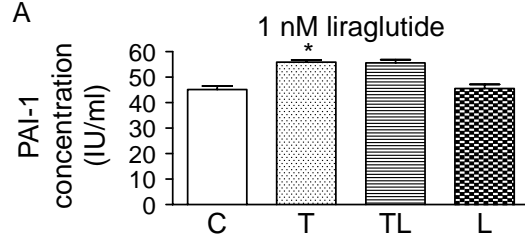

PAI-1 GAPDH

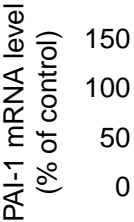

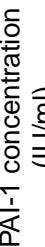

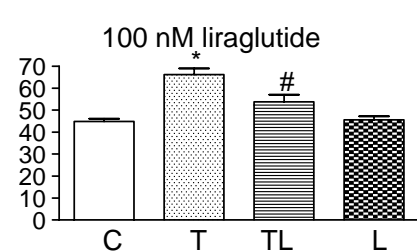

PAI-1 GAPDH

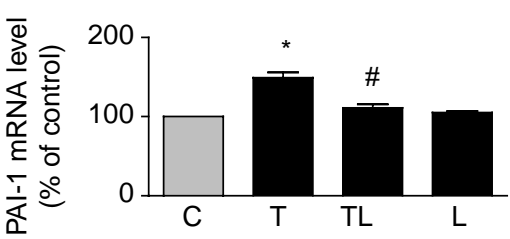

$\mathrm{B}$
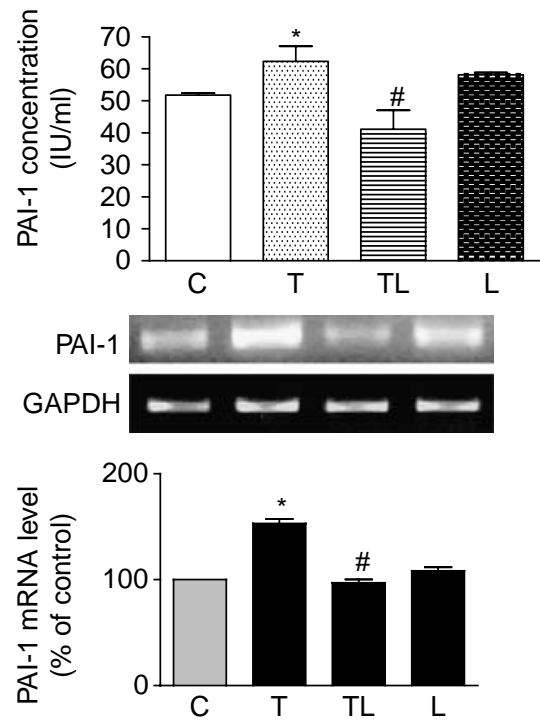

(1)

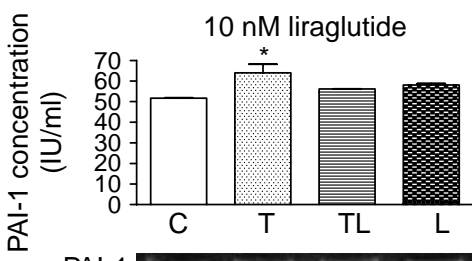

PAl-1 $\longrightarrow$ GAPDH $=-$
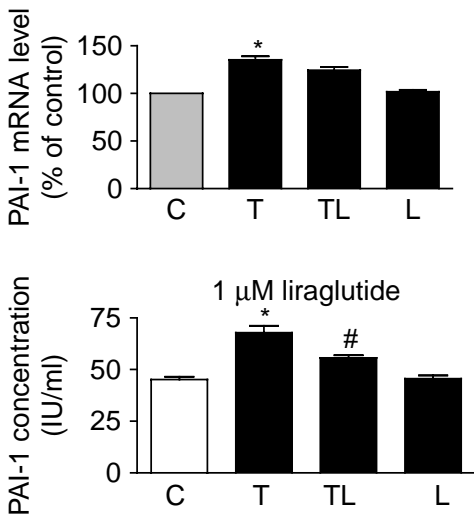

PAI-1 GAPDH
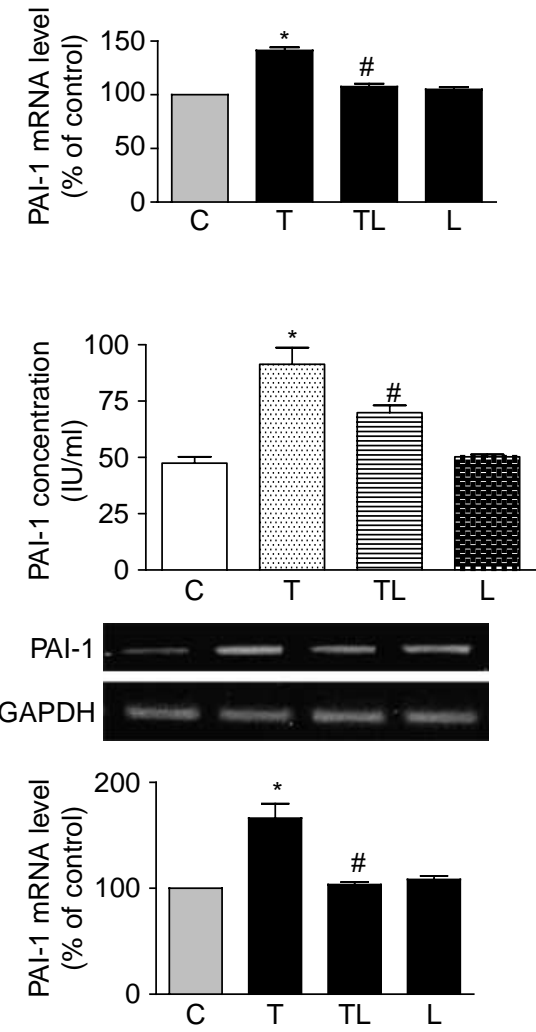

(2) 
The in vitro effects of liraglutide on PAI-1 and vascular adhesion molecule expression, under conditions associated with vascular endothelial cell dysfunction, have not yet been explored. Our study aims to characterize the effects of liraglutide on the regulation of PAI-1 and VCAM-1 expression under conditions of TNF stimulation or hyperglycaemia in human vascular endothelial cells and determine the aspects of the molecular mechanisms responsible for this effect.

\section{Materials and methods}

\section{Materials and cell culture}

Liraglutide was kindly provided by Novo Nordisk, Denmark. The spontaneously transformed human umbilical vein endothelial cell line, C11 STH (Cockerill et al. 1994) was cultured under sterile conditions. Experiments were performed at between three and six cell passages and $80 \%$ cellular confluence at $37^{\circ} \mathrm{C}$ using gelatine-coated Nunclon cell culture dishes in Media-199 (Sigma) supplemented with penicillin/streptomycin, 20\% FCS, $20 \mu \mathrm{g} / \mathrm{ml}$ endothelial cell growth factor (Sigma) and $20 \mu \mathrm{g} / \mathrm{ml}$ heparin. Insulin concentration in FCS was $17.0 \mathrm{pM}$. Glucose concentration in media was $6.0 \mathrm{mM}$.

\section{Determination of PAI-1, ICAM-1 and VCAM-1 proteins}

C11 STH cells were incubated under serum-free conditions with $10 \mathrm{ng} / \mathrm{ml}$ TNF (Promega) pretreatment for 2,5 or $16 \mathrm{~h}$ or with $10 \mathrm{mM}$ glucose for $48 \mathrm{~h}$. Liraglutide $(1 \mathrm{nM}-1 \mu \mathrm{M})$ was added for one hour subsequent to the incubation period with TNF $\alpha$ or concurrently with glucose stimulation. The conditioned medium (CM) was subsequently collected and centrifuged at 10000 revolutions per minute (r.p.m) for $1 \mathrm{~min}$; the PAI-1 protein concentration in the $\mathrm{CM}$ was assayed using a PAI-1 ELISA (Trinity Biotech, Bray, Ireland). The ICAM-1 and VCAM-1 proteins were measured using ELISA kits (R\&D Systems, Minneapolis, MN, USA). All experiments were performed with triplicate incubates and repeated thrice, independently.

\section{Semi-quantitative reverse transcription-PCR (RT-PCR)}

Total RNA was extracted by the method of Chomczynski \& Sacchi (1987). RNA was heated at $65^{\circ} \mathrm{C}$ for $10 \mathrm{~min}$ immediately prior to first-strand cDNA being generated using reverse transcriptase (Invitrogen) with oligo $(\mathrm{dT})_{15}$ primers, in the presence of $1 \mathrm{mM}$ of each dNTP and DTT. For the RT-PCR step, $20 \mu$ reaction volume was used. The primers used for PAI-1 detection were: forward 5'-CAGACCAAGAGCCTCTCCAC-3'; reverse $5^{\prime}$-ATCACTTGGCCCATGAAAAG-3'; VCAM-1: forward 5'-GATACAACCGTCTT GGTCAGCCC- $3^{\prime}$, reverse $5^{\prime}$-CGCATCCTTCAACTGGG CCTT-3'; ICAM-1: forward, 5'-CAGTGACCATCTACAGCTTTCCGG-3' ${ }^{\prime}$, reverse: 5'-GCTGCTACCACAGTGATGATGACAA-3'. The human glyceraldehyde 3-phosphate dehydrogenase (GAPDH) gene was used as an internal control. The forward primer for GAPDH was $5^{\prime}-$ CCTGCACCACCAACTGCTTAGC- $3^{\prime}$ and the reverse primer was $5^{\prime}$-CCAGTGAGCTTCCCGTCTAGC-3'. All PCR products were sequenced to confirm the identities and repeated thrice.

Scanning densitometry analyses were performed on RT-PCR products using the GeneSnap imaging software (Synoptics, Cambridge, UK). Band intensity values for ICAM-1, PAI-1 and VCAM-1 mRNA were normalized to those of GAPDH mRNA and the resultant ICAM-1, PAI-1 and VCAM-1: GAPDH ratios were plotted to illustrate variations in the gene expression.

\section{Real-time PCR}

cDNA was generated as previously described for semiquantitative RT-PCR. For real-time PCR, volumes were made up to $20 \mu \mathrm{l}$ and contained SYBR Green 1 Buffer (QIAGEN, Hilden, Germany); forward and reverse primers used for $\beta$-actin detection were $5^{\prime}$-GACAGGATGCAGAAGGAGATTACT-3' and $5^{\prime}$-TGATCCACATCTGCTGGAAGGT- $3^{\prime}$ and NUR77 were $5^{\prime}$-GCTGCAGAATGAC TCCACC- $3^{\prime}$ and $5^{\prime}$-ACAGCAGCACTGGGCTTA-3'. Samples were run in duplicate with RNA preparations from three independent experiments. Real-time PCR was performed at 50 cycles $\left(15 \mathrm{~s}\right.$ at $95^{\circ} \mathrm{C}, 56 \mathrm{~s}$ at $56^{\circ} \mathrm{C}$ and $45 \mathrm{~s}$ at $68^{\circ} \mathrm{C}$ ), and each PCR run also included triplicate wells of no template control. A melting point dissociation curve generated by the instrument was used to confirm that only a single product was present. The fluorescence resulting from the incorporation of SYBR Green 1 dye into the double-stranded DNA produced during the PCR, and emission data were quantitated using the threshold cycle $\left(C_{t}\right)$ value. Data were normalized to $\beta$-actin and presented as the mean fold change compared with control.

\section{Statistical analysis}

The effects of the agents on ICAM-1, VCAM-1 and PAI-1 protein production and mRNA expression were assessed by

Figure 1 (A) Dose response of liraglutide on 2-h TNF-stimulated induction of PAI-1 mRNA and protein secretion in C11 STH cells. C, control; T, TNF (10 ng/ml); TL, TNF + liraglutide; L, liraglutide $\left(n=3 ;{ }^{*} P<0 \cdot 05\right.$, T versus $C, \# P<0 \cdot 01$, T versus TL). (B) Effects of liraglutide treatment on basal and TNF-induced PAI-1 mRNA and protein secretion in C11 STH cells. (B (1)) Cells pretreated with TNF (10 ng/ml) for $5 \mathrm{~h}$, and $100 \mathrm{nM}$ liraglutide was added with TNF for $1 \mathrm{~h}$ subsequent to the 5-h incubation period. (B (2)) Cells pretreated with TNF (10 ng/ml) for $16 \mathrm{~h}$, and $100 \mathrm{nM}$ liraglutide was added with TNF for $1 \mathrm{~h}$ subsequent to the 16 - $\mathrm{h}$ incubation period. C, control; T, TNF (10 ng/ml); TL, TNF + liraglutide; $\mathrm{L}$, liraglutide $(n=3, * P<0 \cdot 05, \mathrm{~T}$ versus $\mathrm{C}, \# P<0 \cdot 01$, T versus TL). 

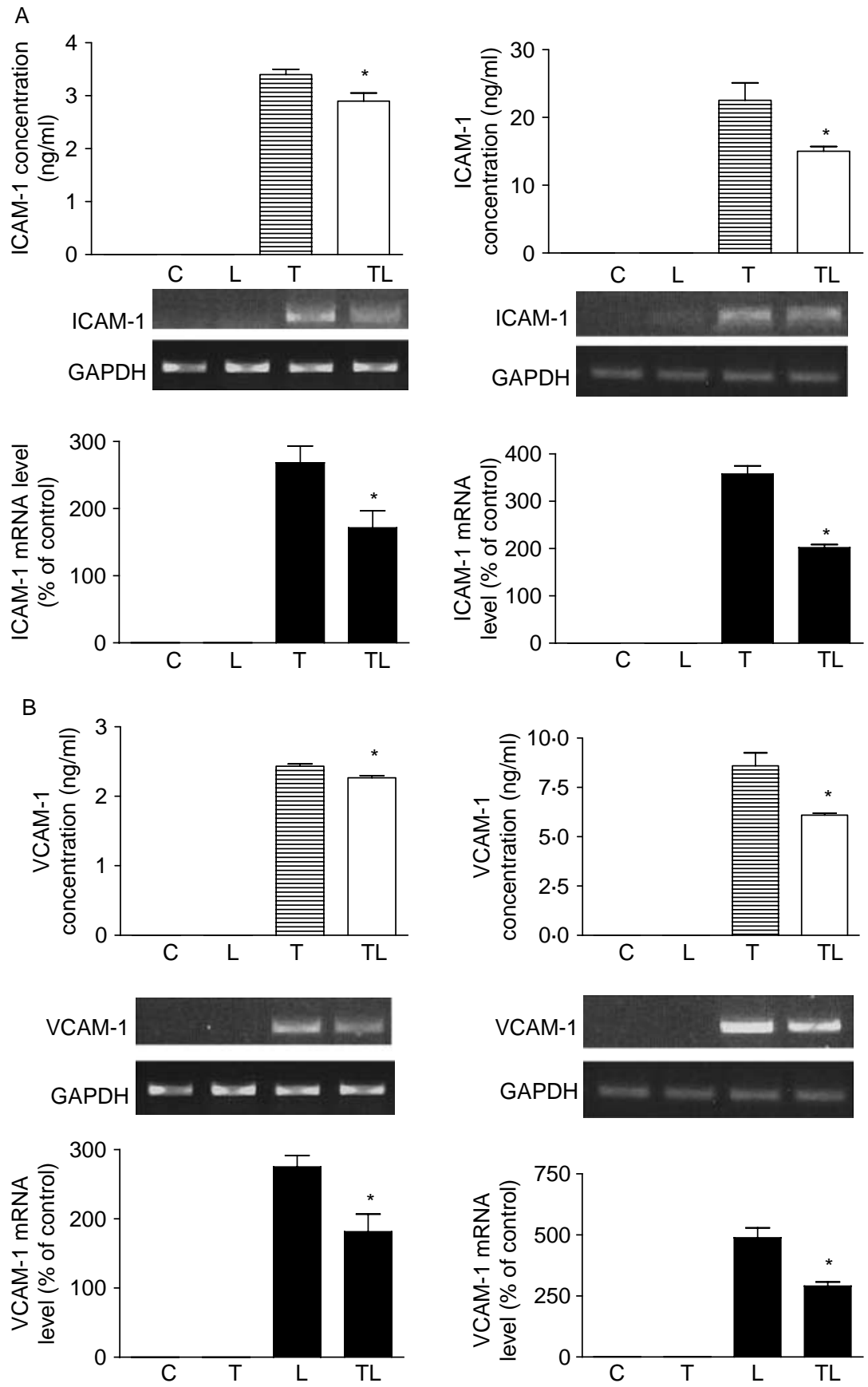

(1)

(2)

Figure 2 (A) Effects of liraglutide treatment on basal and TNF-induced ICAM-1 mRNA and protein secretion in $\mathrm{C} 11 \mathrm{STH}$ cells pretreated with TNF $(10 \mathrm{ng} / \mathrm{ml})$ for $5 \mathrm{~h} \mathrm{(1)} \mathrm{or} 16 \mathrm{~h}(2)$ and $100 \mathrm{nM}$ liraglutide were added with TNF for $1 \mathrm{~h}$ subsequent to the 5- or 16-h incubation period. C, control; T, TNF; TL, TNF + liraglutide; L, liraglutide $100 \mathrm{nM}\left(n=3 ;{ }^{*} P<0 \cdot 05\right.$, $\mathrm{T}$ versus $\mathrm{TL}$ ). (B) Effects of liraglutide treatment on basal and TNF-induced VCAM-1 mRNA and protein secretion in C11 STH cells pretreated with TNF (10 ng/ml) for $5 \mathrm{~h}$ (1) or $16 \mathrm{~h} \mathrm{(2)}$ and $100 \mathrm{nM}$ liraglutide were added with TNF for $1 \mathrm{~h}$ subsequent to the 5 - or 16 - $\mathrm{h}$ incubation period. C, control; T, TNF; TL, TNF + liraglutide; L, liraglutide $100 \mathrm{nM}\left(n=3 ;{ }^{*} P<0 \cdot 05\right.$, $\mathrm{T}$ versus $\mathrm{TL})$. 

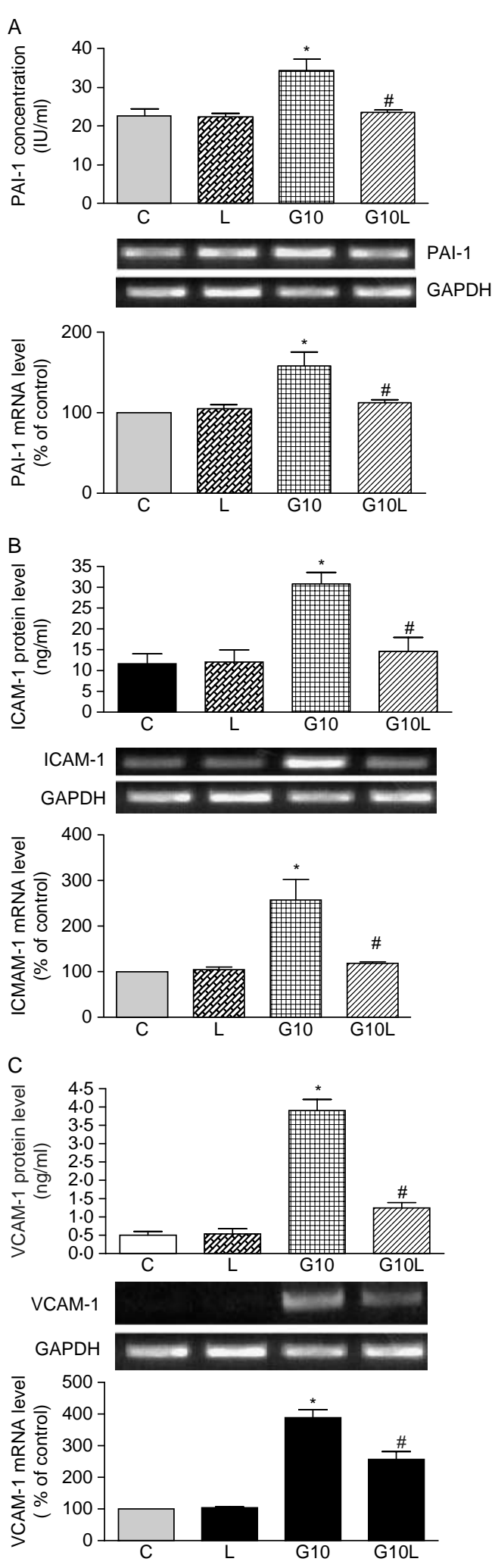

www.endocrinology-journals.org
ANOVA. Specific differences were tested with Bonferroni's post hoc comparison test. Data were expressed as mean \pm s.E.M. and $P<0.05$ was considered statistically significant.

\section{Results}

Liraglutide inhibits TNF-inducible PAI-1 protein expression in C11 STH cells

TNF treatment $(10 \mathrm{ng} / \mathrm{ml})$ resulted in a significant increase in PAI-1 mRNA and protein expression (Fig. 1A). Liraglutide dose response demonstrated that the addition of liraglutide at low concentrations ( 1 and $10 \mathrm{nM}$ ) demonstrated a nonsignificant trend towards the inhibition of TNF-mediated induction of PAI-1 expression. An addition of $100 \mathrm{nM}$ or $1 \mu \mathrm{M}$ liraglutide significantly attenuated $2-\mathrm{h}$ TNF-mediated induction of PAI-1 expression at $2 \mathrm{~h}$ to control levels (Fig. 1A). The $100 \mathrm{nM}$ liraglutide treatment also significantly attenuated either 5- or 16-h TNF-mediated induction of PAI-1 mRNA and protein expression to control levels utilizing 5-h TNF pretreatment (Fig. 1B).

\section{Liraglutide inhibits TNF-mediated ICAM-1 and VCAM-1 expression in C11 STH cells}

Minimal constitutive expression of ICAM-1 or VCAM-1 was observed (Fig. 2A and B) in the C11 STH cell line. Liraglutide alone $(100 \mathrm{nM})$ had no effect on constitutive ICAM-1 and VCAM-1 mRNA or protein expression (Fig. 2A and B). The 5- or 16-h TNF pretreatment $(10 \mathrm{ng} / \mathrm{ml})$ significantly induced ICAM-1 and VCAM-1 mRNA and protein expression (Fig. 2A and B). The 2-h TNF pretreatment resulted in no induction of ICAM-1 or VCAM-1 mRNA or protein expression (data not shown). Treatment with $100 \mathrm{nM}$ liraglutide significantly attenuated 5and 16-h pretreatment of TNF-mediated induction of ICAM-1 and VCAM-1 mRNA and protein expression (Fig. 2A and B).

Liraglutide inhibits hyperglycaemia-mediated PAI-1, ICAM-1 and VCAM-1 expression in C11 STH cells

The $10 \mathrm{mM}$ glucose treatment significantly induced PAI-1, ICAM-1 and VCAM-1 mRNA and protein expression at

Figure 3 (A) Effects of liraglutide on hyperglycaemia-induced PAI-1 mRNA and protein secretion in C11 STH cells, C, control; L, liraglutide $100 \mathrm{nM}$; G10, $10 \mathrm{mM}$ glucose; G10L, $10 \mathrm{mM}$ glucose + liraglutide; $\left(n=3{ }^{*} P<0 \cdot 05, \mathrm{G} 10\right.$ versus $\mathrm{C} ; \# P<0 \cdot 01, \mathrm{G} 10$ vs $\left.\mathrm{G} 10 \mathrm{~L}\right)$. (B) Effects of liraglutide on hyperglycaemia-induced ICAM-1 mRNA and protein secretion in $\mathrm{C} 11$ STH cells, C, control; L, liraglutide $100 \mathrm{nM}$; G10, 10 mM glucose; G10L, $10 \mathrm{mM}$ glucose+liraglutide; $(n=3 ; * P<0 \cdot 05, \mathrm{G} 10$ versus $\mathrm{C} ; \# P<0 \cdot 01, \mathrm{G} 10$ vs G10L). (C) Effects of liraglutide on high-glucose-induced VCAM-1 mRNA and protein secretion in C11 STH cells, C, control; L, liraglutide $100 \mathrm{nM}, \mathrm{G} 10$, $10 \mathrm{mM}$ glucose; G10L, $10 \mathrm{mM}$ glucose + liraglutide; $(n=3$;

${ }^{*} P<0 \cdot 05, \mathrm{G} 10$ versus $\mathrm{C} ; \# P<0 \cdot 01, \mathrm{G} 10$ vs G10L). 
$48 \mathrm{~h}$ (Fig. 3A, B and C). Treatment of C11 STH cells with $100 \mathrm{nM}$ liraglutide alone had no effect on the constitutive PAI-1, ICAM-1 and VCAM-1 expression (Fig. 3A, B and C). Treatment with $100 \mathrm{nM}$ liraglutide significantly attenuated $10 \mathrm{mM}$ glucose-mediated induction of PAI-1, ICAM-1 and VCAM-1 mRNA and protein expression at $48 \mathrm{~h}$ to control levels (Fig. 3A, B and C). A similar inhibitory response to $20 \mathrm{mM}$ glucose induction of ICAM-1 and VCAM-1 by $100 \mathrm{nM}$ liraglutide was also observed (data not shown).

\section{Liraglutide inhibits TNF and hyperglycaemia-mediated}

expression of the orphan nuclear receptor NUR77 in C11 STH cells

The 5- or $16-\mathrm{h}$ TNF pretreatment $(10 \mathrm{ng} / \mathrm{ml})$ or $10 \mathrm{mM}$ glucose for $48 \mathrm{~h}$ significantly induced Nur77 mRNA expression (Fig. 4A, B and C). Liraglutide alone (100 nM) had no effect on basal Nur77 mRNA expression (Fig. 4A, B and C). Liraglutide treatment $(100 \mathrm{nM})$ significantly attenuated TNF and glucose-mediated induction of Nur $77 \mathrm{mRNA}$ expression to control levels (Fig. 4A, B and C).

\section{Discussion}

Increased expression of PAI-1 and vascular adhesion molecules have been observed in vascular endothelial cells stimulated by TNF or high glucose (Morigi et al. 1998, Sobel et al. 1998, Blankenberg et al. 2003, Liu et al. 2005, 2008, Norata et al. 2006, Kumar et al. 2007, Iwasaki et al. 2008), and are present in the plasma of patients with type 2 diabetes (Juhan-Vague et al. 1991, Steiner et al. 1994, Marfella et al. 2000, Peschel \& Niebauer 2003). Elevated levels of PAI-1 and vascular adhesion molecules are associated with vascular endothelial cell dysfunction and may predispose patients to accelerated atherogenesis in the metabolic syndrome and type 2 diabetes (Juhan-Vague et al. 1991, Steiner et al. 1994, Marfella et al. 2000, Peschel \& Niebauer 2003).

Previously we demonstrated that GLP-1 attenuates TNFmediated induction of PAI-1 expression (Liu et al. 2008) and have been interested in the effects of liraglutide, an acylated long-acting GLP-1 analogue, on TNF- or high-glucoseinduced PAI-1 and vascular adhesion molecule gene and protein expression in human vascular endothelial cells. We demonstrate for the first time, in a human cell system, that liraglutide attenuates TNF and high-glucose-induced PAI-1, ICAM-1 and VCAM-1 gene and protein expression in vascular endothelial cells.

TNF or high glucose activates transcription of adhesion molecules including ICAM-1 and VCAM-1 via translocation of $\mathrm{NFKB}$ from the cytoplasm into the cell nucleus with subsequent induction of gene expression (Morigi et al. 1998, Norata et al. 2006). TNF activates transcription of PAI-1 via modulation of NUR77 expression and binding to the NBREbinding site in the PAI-1 gene promoter (Gruber et al. 2003, Liu et al. 2005, 2008). In addition, GLP-1-mediated inhibition
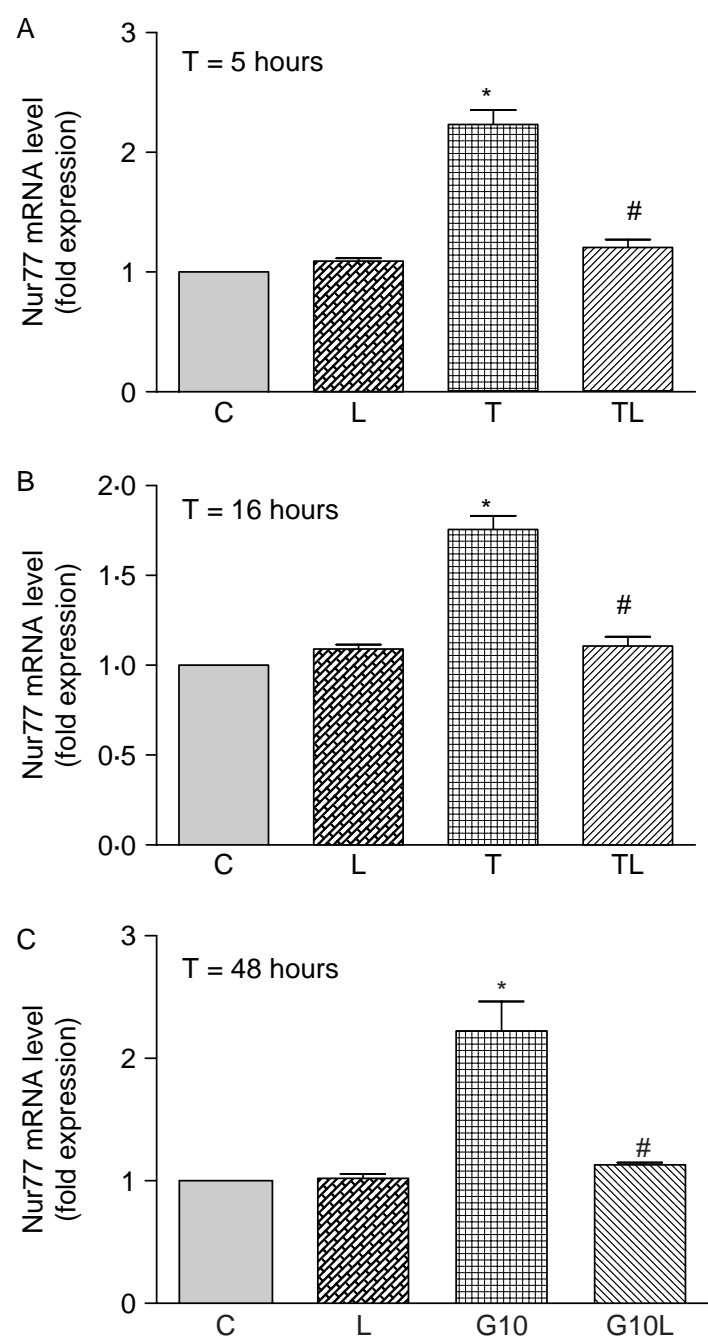

Figure 4 Real-time Q-PCR of the effects of liraglutide treatment on Nur77 mRNA expression. C, control; T, TNF (10 ng/ml); G10, $10 \mathrm{mM}$ glucose; L, liraglutide $100 \mathrm{nM}$; G10L, $10 \mathrm{mM}$ glucose + liraglutide; TL, TNF+liraglutide; $\left(n=3 ;{ }^{*} P<0 \cdot 05, \mathrm{G} 10\right.$ or T versus C; $\# P<0 \cdot 01, \mathrm{G} 10$ or $\mathrm{T}$ versus $\mathrm{G} 10 \mathrm{~L}$ or $\mathrm{TL}$ ). (A) 5 -h TNF treatment, (B) 16-h TNF treatment, and (C) 48-h $10 \mathrm{mM}$ glucose treatment.

of TNF-induced PAI-1 expression is associated with the suppression of NUR77 expression (Liu et al. 2008). Recent studies also demonstrate that high glucose induces PAI-1 expression through Rho/Rho-kinase-mediated NFKB activation in bovine aortic endothelial cells (Iwasaki et al. 2008). Also, GLP-1 together with glucose has been reported to modulate expression of NUR77 in the pancreatic $\beta$ cell line, INS-1 (Susini et al. 1998).

To investigate the molecular mechanisms responsible for liraglutide-mediated inhibition of TNF- or high-glucoseinduced PAI-1, ICAM-1 and VCAM-1 gene and protein expression, we explored the effects of liraglutide on Nur77 mRNA expression. Our results demonstrate that the liraglutide treatment decreases TNF- and high-glucose-mediated 
induction of Nur77 mRNA expression, which is consistent with a possible molecular mechanism responsible for liraglutide's inhibition of elevated PAI-1, ICAM-1 and VCAM-1 expression under conditions of TNF and high-glucose stimulation.

Whilst the PAI-1 promoter has a recognized cis-acting element for NUR77 (NBRE; Gruber et al. 2003), it is currently unclear how liraglutide may regulate expression of ICAM-1 and VCAM-1 genes. It is of interest, however, that both ICAM-1 and VCAM-1 gene promoters harbour NUR77 cis-acting elements, which could mediate this effect (www.genomatrix.de/cgi-bin/matinspector).

Previous studies have demonstrated the involvement of NFKB in TNF- or high-glucose-induced PAI-1, ICAM-1, VCAM-1 expression (Morigi et al. 1998, Norata et al. 2006, Iwasaki et al. 2008). Interestingly, the NUR77 promoter harbours NFKB cis-acting regulatory elements (Pei et al. 2005), and the effects of liraglutide on this trans-acting factor and subsequent NUR77-mediated inhibition of induction of PAI-1, ICAM-1 and VCAM-1 warrant further investigation.

In summary, this in vitro study is the first to demonstrate liraglutide-mediated attenuation of TNF or high-glucosemediated induction of PAI-1, ICAM-1 and VCAM-1 expression in human vascular endothelial cells. A postulated molecular mechanism responsible for this effect may involve regulation of NUR77 expression. These results indicate a potential role for liraglutide in the inhibition of endothelial cell dysfunction in type 2 diabetes and the metabolic syndrome. In addition, they complement recent in vivo studies demonstrating the beneficial effects of GLP-1 on endothelial cell dysfunction in diabetic patients (Nyström et al. 2004), which may, subject to the results of future studies, translate into improved cardiovascular outcomes in this patient population.

\section{Declaration of interest}

This work was funded in part by Novo Nordisk, Denmark.

\section{Funding}

This work was financially supported by Monash University and in-part by Novo Nordisk, Denmark.

\section{Acknowledgements}

Dr Lotte B Knudsen for provision of liraglutide.

\section{References}

Blankenberg S, Barbaux S \& Tiret L 2003 Adhesion molecules and atherosclerosis. Atherosclerosis 170 191-203.
Chomczynski P \& Sacchi N 1987 Single-step method of RNA isolation by acid guanidinium thiocyanate-phenol-chloroform extraction. Analytical Biochemistry 162 156-159.

Cockerill GW, Meyer G, Noack L, Vadas MA \& Gamble JR 1994 Characterization of a spontaneously transformed human endothelial cell line. Laboratory Investigation 71 497-509.

Degn KB, Juhl CB, Sturis J, Jakobsen G, Brock B, Chandramouli V, Rungby J, Landau BR \& Schmitz O 2004 One week's treatment with the long-acting glucagon-like peptide 1 derivative liraglutide (NN2211) markedly improves 24-h glycemia and alpha- and beta-cell function and reduces endogenous glucose release in patients with type 2 diabetes. Diabetes 53 1187-1194.

Eitzman DT, Westrick RJ, Xu Z, Tyson J \& Ginsburg D 2000 Plasminogen activator inhibitor-1 deficiency protects against atherosclerosis progression in the mouse carotid artery. Blood 96 4212-4215.

Elbrønd B, Jakobsen G, Larsen S, Agersø H, Jensen LB, Rolan P, Sturis J, Hatorp V \& Zdravkovic M 2002 Pharmacokinetics, pharmacodynamics, safety, and tolerability of a single-dose of NN2211, a long-acting glucagonlike peptide 1 derivative, in healthy male subjects. Diabetes Care $\mathbf{2 5}$ 1398-1404.

Golpon HA, Puechner A, Welte T, Wichert PV \& Feddersen CO 2001 Vasorelaxant effect of glucagon-like peptide-(7-36) amide and amylin on the pulmonary circulation of the rat. Regulatory Peptides 102 81-86.

Gruber F, Hufnagl P, Hofer-Warbinek R, Schmid JA, Breuss JM, Huber-Beckmann R, Lucerna M, Papac N, Harant H, Lindley I et al. 2003 Direct binding of Nur77/NAK-1 to the plasminogen activator inhibitor 1 (PAI-1) promoter regulates TNF alpha -induced PAI-1 expression. Blood $1013042-3048$

Hobb FD 2006 Type-2 diabetes mellitus related cardiovascular risk: new options for interventions to reduce risk and treatment goals. Atherosclerosis 7 29-32.

Iwasaki H, Okamoto R, Kato S, Konishi K, Mizutani H, Yamada N, Isaka N, Nakano T \& Ito M 2008 High glucose induces plasminogen activator inhibitor-1 expression through Rho/Rho-kinase-mediated NF-kappaB activation in bovine aortic endothelial cells. Atherosclerosis 196 22-28.

Juhan-Vague I, Alessi MC \& Vague P 1991 Increased plasma plasminogen activator inhibitor 1 levels: a possible link between insulin resistance and atherothrombosis. Diabetologia 34 457-462.

Juhl CB, Hollingdal M, Sturis J, Jakobsen G, Agersø H, Veldhuis J, Pørksen N \& Schmitz O 2002 Bedtime administration of NN2211, a long-acting GLP-1 derivative, substantially reduces fasting and postprandial glycemia in type 2 diabetes. Diabetes $\mathbf{5 1}$ 424-429.

Kumar S, Sharma A, Madan B, Singhal V \& Ghosh B 2007 Isoliquiritigenin inhibits I $\mathrm{B}$ kinase activity and ROS generation to block TNF-alpha induced expression of cell adhesion molecules on human endothelial cells. Biochemical Pharmacology 73 1602-1612.

Liu HB, Hu YS, Medcalf RL, Simpson RW \& Dear AE 2005 Thiazolidinediones inhibit TNFalpha induction of PAI-1 independent of PPARgamma activation. Biochemical and Biophysical Research Communications 334 30-37.

Liu HB, Hu YS, Simpson RW \& Dear AE 2008 Glucagon-like peptide-1 attenuates tumour necrosis factor-alpha-mediated induction of plasmogen activator inhibitor-1 expression. Journal of Endocrinology 196 57-65.

Mao LJ, Mao SL, Taylor KL, Kanjanabuch T, Guan Y, Zhang Y, Brown N, Swift LL, McGuinness OP, Wasserman DH et al. 2004 Prevention of obesity and insulin resistance in mice lacking plasminogen activator inhibitor 1. Diabetes 53 336-346.

Marfella R, Esposito K, Giunta R, Coppola G, De Angelis L, Farzati B, Paolisso G \& Giugliano D 2000 Circulating adhesion molecules in humans: role of hyperglycemia and hyperinsulinemia. Circulation 101 2247-2251.

Morigi M, Angioletti S, Imberti B, Donadelli R, Micheletti G, Figliuzzi M, Remuzzi A, Zoja C \& Remuzzi G 1998 Leukocyte-endothelial interaction is augmented by high glucose concentrations and hyperglycemia in a NFкB-dependent fashion. Journal of Clinical Investigation 101 1905-1915.

Norata GD, Tibolla G, Seccomandi PM, Poletti A \& Catapano AL 2006 Dihydrotestosterone decreases tumor necrosis factor-alpha and lipopolysaccharide-induced inflammatory response in human endothelial cells. Journal of Clinical Endocrinology and Metabolism 91 546-554. 
Nyström T, Gutniak MK, Zhang Q, Zhang E, Holst JJ, Ahren B \& Sjöholm A 2004 Effects of glucagon like peptide on endothelial function in type 2 diabetes patients with stable coronary artery disease. American Journal of Physiology. Endocrinology and Metabolism 287 E1209-E1215.

Pei L, Castillo A, Chen M, Hoffmann A \& Tontonoz P 2005 Induction of NR4A orphan nuclear receptor expression in macrophages in response to inflammatory stimuli. Journal of Biological Chemistry 280 29256-29262.

Peschel T \& Niebauer J 2003 Role of pro-atherogenic adhesion molecules and inflammatory cytokines in patients with coronary artery disease and diabetes mellitus type 2. Cytometry. Part B, Clinical Cytometry 53 78-85.

Sobel BE, Woodcock-Mitchell J, Schneider DJ, Holt RE, Marutsuka K \& Gold H 1998 Increased plasminogen activator inhibitor type 1 in coronary artery atherectomy specimens from type 2 diabetic compared with nondiabetic patients: a potential factor predisposing to thrombosis and its persistence. Circulation 97 2213-2221.

Steiner M, Reinhardt KM, Krammer B, Ernst B \& Blann AD 1994 Increased levels of soluble adhesion molecules in type 2 (non-insulin-dependent) diabetes mellitus are independent of glycaemic control. Thrombosis and Haemostasis 72 979-984.
Susini S, Roche E, Prentki M \& Schlegel W 1998 Glucose and glucoincretin peptide synergize to induce c-fos, c-jun, junB, zif-268, and nur-77 gene expression in pancreatic beta (INS-1) cells. FASEB Journal 12 1173-1182.

Vilsboll T, Zdravkovic M, Le-Thi T, Krarup T, Schmitz O, Courrèges JP, Verhoeven R, Bugánová I \& Madsbad S 2007 Liraglutide, a long-acting human GLP-1 analog, given as monotherapy significantly improves glycemic control and lowers body weight without risk of hypoglycemia in patients with type 2 diabetes mellitus. Diabetes Care 30 1608-1610.

Yu M, Moreno C, Hoagland KM, Dahly A, Ditter K, Mistry M \& Roman RJ 2003 Antihypertensive effect of glucagon-like peptide 1 in Dahl saltsensitive rats. Journal of Hypertension 21 1125-1135.

\section{Received in final form 15 December 2008 \\ Accepted 9 January 2009 \\ Made available online as an Accepted Preprint \\ 9 January 2009}

